\title{
Homonationalism: resisting nationalist co-optation of sexual diversity
}

\section{Richard C.M. Mole, School of Slavonic and East European Studies, University College London}

Historically, attempts by nationalists to forge a connection between nationality and sexuality (the lack of any a priori relationship notwithstanding) have generally been made with the aim of reinforcing the supposed heterosexuality of the nation so as to legitimise the marginalisation of and violence towards sexual minorities. While it would be wrong to assume that all nationalists are homophobic, research shows that those who ascribe to the commonly held belief that nations should be seen as extended kin groups, united by a shared bloodline and common descent (all academic evidence to the contrary), are often more likely to have a heteronormative understanding of and strict rules on sexuality (Greenberg, 2006; Inglehart \& Baker, 2000; Mole, 2011; Nagel, 2000; Yuval-Davis, 1997). As the continued existence of the nation as well as its internal homogeneity and demarcation from the Other are believed to result from endogenous biological reproduction and are underpinned by heteronormative conceptions of masculinity and femininity, sexual minorities are often perceived as posing a threat to the national community by undermining the family, failing to adhere to national gender stereotypes, challenging its internal homogeneity and deviating from shared national norms, especially those derived from religious teaching. The acceptance of this discourse as taken-for-granted by large swathes of the population further allows nationalist politicians to instrumentalise homosexuality, using nonnormative sexuality as a lightning rod to divert attention away from economic and political problems or to reject criticism of illiberal practices - all in the name of defending the nation.

More recently, however, we have seen attempts to make nation-states more inclusive of sexual minorities and supportive of LGBTQ rights. In principle, any moves to ensure that LGBTQ individuals for whom national identity is an important aspect of their sense of self are not made to feel excluded should be welcomed; as psychologists argue, identification with social groups - including nations - can provide a sense of belonging and self-esteem (Tajfel and Turner, 1986). While the incorporation of LGBTQ individuals as full members of the nation, state support for LGBTQ rights and the identification of LGBTQ individuals with their national cultures are not problematic per se, these practices become dangerous when only certain kinds of LGBTQ people are considered to be acceptable members of the nation, when LGBTQ communities use the rhetoric of nationalism to exclude undesired groups and when LGBTQ inclusion is used by nation-states as a means of creating moral hierarchies vis-à-vis national, racial and religious Others - processes known collectively as 'homonationalism' (Puar, 2007). In Puar's own words, homonationalism is 'the use 
of 'acceptance' and 'tolerance' for gay and lesbian subjects as the barometer by which the legitimacy of and capacity for national sovereignty is evaluated'; the 'embracing of nationalist and often xenophobic and imperialist interests' by LGBT communities; and 'a critique of how lesbian and gay liberal rights discourses produce narratives of progress and modernity that continue to accord some populations access to cultural and legal forms of citizenship at the expense of the partial and full expulsion from those rights of other populations' (2013, 23-25). In Terrorist Assemblages Puar shows how 'homonationalism' as an analytic category helps us understand how the US government uses a specific conceptualisation of sexuality to legitimise counterterrorism actions against Sikhs, Muslims, and Arabs at home and abroad. Drawing on these insights, the aim of this special issue is to demonstrate how Puar's ideas can be usefully applied to a broad range of themes, policy areas and case studies in Europe, North America, Africa and the Middle East.

The issue of asylum is examined by two contributors. Thibaut Raboin analyses discourses on LGBTI asylum in the UK, focusing in particular on the relationship between liberalism, nationhood and hospitality. Looking firstly at narratives of asylum cases, the article shows how they create a specific temporality, where queer futures are deemed impossible outside of the UK. Then, it looks at how the tropes of the domestic homophobic past and the homophobic elsewhere interact in discourses to produce a unique type of politicisation of asylum, whereby British liberal queers can be invested in defending the rights of LGBTI asylum seekers. Finally, the article unpacks what constitutes the promise of 'happy queer futures' in the UK to show that homonationalism is more than a collusion between certain gay and lesbian subjectivations and the liberal state but rather provides complex ways of understanding and articulating sexuality, nationhood and homonormative practices.

The theme of asylum is also examined by Cheryl Llewellyn in her article on sexual orientation-based asylum cases in the United States. Llewellyn highlights the analytical distinction between sexual orientation-based asylum cases that use the narrative of the 'homosexual' versus those employing other less (homo)normative sexual identities. Arguing that in the asylum system the 'homosexual' is a unitary and fixed identity characterised by visibility, coherence and linearity - features which are consistent with a homonormative identity construction that privileges white, Western, gay male sexual politics - her analysis demonstrates that applicants who can adopt the narrative of the 'homosexual' have greater success than applicants' identities that are not easily encapsulated by this single narrative.

Interaction between Western and non-Western subjects is also the focus of Armanc Yıldı's research on the participation of a Turkish Boat in Amsterdam's Gay Pride. Showing how the Dutch media consistently emphasised what an 
advancement this participation was for the Turkish migrants, considering their 'cultural background', Yıldız's article highlights the Orientalising tendencies in Dutch newspapers, which celebrated the Turkish Boat but at the same time reproduced hierarchies of 'progressive tolerant Dutch people' versus 'backwards Muslim immigrants'.

Homonationalist media practices are also examined in Katarina Jungar and Salla Peltonen's article. By analysing the mapping by Swedish newspapers of anti-homosexuality laws in Africa, which the authors understand as instances of imaginative geographies, Jungar and Peltonen investigate how journalistic rhetoric about homophobia on the African continent relies on a politics of homonationalism and sexual exceptionalism in 'gay liberation' discourses.

The final article in this special issue, by Gilly Hartal and Orna Sasson-Levy, examines the Gay-Center in Tel Aviv, Israel. This article focuses on the Gay-Center as a material, symbolic and discursive space in order to clarify the relationship between LGBT individuals and the nation. Hartal and Sasson-Levy show that the attempts at LGBT mainstreaming with the aim of accelerating the achievement of sexual citizenship and urban belonging - inevitably involve processes of inclusion and exclusion, revealing a range of homonationalist practices and homonormative discourses.

\section{References}

Greenberg, J. 2006, Nationalism, masculinity and multicultural citizenship in Serbia. Nationalities Papers. 34, 321-41. Inglehart, R. and Baker, W.E. 2000. Modernization, cultural change, and the persistence of traditional values. American Sociological Review. 65, 19-51.

Mole, R.C.M. 2011. Nationality and sexuality: homophobic discourse and the 'national threat' in contemporary Latvia. Nations and Nationalism. 17, 540-560.

Nagel, J. 2000. Ethnicity and sexuality. Annual Review of Sociology. 26, 107-33.

Puar, J.K. 2013. Homonationalism as assemblage: viral travels, affective sexualities. Jindal Global Law Review. 4, 2342.

Puar, J.K. (2007) Terrorist Assemblages: Homonationalism in Queer Times. Durham, NC: Duke University Press

Tajfel, H. and Turner, J.C. (1986) 'The social identity theory of intergroup behaviour' in Worchel, S. and Austin, W.G. (eds) Psychology of intergroup relations. Chicago: Nelson Hall.

Yuval-Davis, N. 1997. Gender and Nation, London: Sage Publications Ltd. 